\title{
Corrigendum: Critical exponents and scaling invariance in the absence of a critical point
}

\author{
N. Saratz, D.A. Zanin, U. Ramsperger, S.A. Cannas, D. Pescia \& A. Vindigni
}

Nature Communications 7:13611 doi: 10.1038/ncomms13611 (2016); Published 5 Dec 2016; Updated 17 Jan 2017

The original version of this Article contained a typographical error in the spelling of the author S.A. Cannas, which was incorrectly given as S. Cannas. This has now been corrected in both the PDF and HTML versions of the Article.

\footnotetext{
(c) This work is licensed under a Creative Commons Attribution 4.0 International License. The images or other third party material in this article are included in the article's Creative Commons license, unless indicated otherwise in the credit line; if the material is not included under the Creative Commons license, users will need to obtain permission from the license holder to reproduce the material. To view a copy of this license, visit http://creativecommons.org/licenses/by/4.0/
}

(C) The Author(s) 2017 